Student Success

ISSN: 2205-0795

Volume 8, Issue 2, pp. 95-99

J uly 2017

\title{
Live, Learn, Grow: Supporting young people with a care experience through higher education
}

\author{
Louise Rak and Emily Fuller
}

University of Newcastle, Newcastle, Australia

\section{Abstract*}

Developed through research and community collaboration with the out-of-home care (OOHC) sector, including people with lived experience and local providers, Live, Learn, Grow aims to address some of the barriers faced by care leavers in learning about, accessing and engaging in higher education. Over 40,000 children and young people in Australia are currently in OOHC. Research shows Australians who have a previous OOHC experience are less likely to commence and complete tertiary education, and more likely to be unemployed, or employed in low paid, low skilled roles. Through collaboration with local agencies, Live, Learn, Grow has provided information about higher education pathways to young people in care, as well as on-campus experience days. The Navigator/Linker role has also provided support for first-year university students, with participants highlighting this support as a key factor in their decision to remain engaged in university study past their first month.

*This 'Emerging Initiative' was first presented at the 2017 STARS Conference in Adelaide, Australia in July 2017 and was selected by the Conference Committee as one of the top-rated reports. The authors have kindly given their permission to have this report published in this special issue of the Journal and it has undergone a further review by the editors to confirm it aligns with the Journal format.

Please cite this article as:

Rak, L., \& Fuller, E. (2017). Live, Learn, Grow: Supporting young people with a care experience through higher education. Student Success, 8(2), 95-99. doi: 10.5204/ssj.v8i2.385

This practice report has been accepted for publication in Student Success. Please see the Editorial Policies under the 'About' section of the Journal website for further information.

Student Success: A journal exploring the experiences of students in tertiary education

(c) (i) This work is licensed under a Creative Commons Attribution 4.0 International Licence. As an open access journal, articles are free to use, with proper attribution, in educational and other non-commercial settings. ISSN: 2205-0795 


\section{Live, Learn, Grow}

Live, Learn, Grow (LLG) is an innovative project developed by the University of Newcastle (UON) Centre of Excellence for Equity in Higher Education (CEEHE) that seeks to overcome the known barriers preventing care leavers engaging with higher education. LLG was developed in consultation with people with a lived experience of the care system, government and non-government caseworkers, agency staff, and academic staff and researchers. Subsequently, the program has ongoing and active support from internal and external stakeholders involved in education and the out-of-home care (OOHC) system. The reasons for the under representation of people with a care experience in higher education are varied and complex (Beauchamp, 2014). LLG aims to address the key factors driving care leavers' limited engagement in education in order to give this group the best chance at reaching their potential. Highly ranked among these factors is the need to illuminate education as a realistic and achievable goal for care leavers.

Over 40,000 children and young people are in OOHC in Australia (Australian Institute of Health and Welfare, 2011). The Hunter and Central Coast region is overrepresented in both risk of significant harm child protection reports and OOHC placements, experiencing significant and consistently high numbers of children and young people entering and staying in $\mathrm{OOHC}$ (NSW Family and Community Services, 2014). Over $10 \%$ of $00 \mathrm{HC}$ placements are in the Central Coast Hunter New England region, with this region consistently ranked in the top three regions for New South Wales for the number of children and young people placed into statutory care (NSW Family and Community Services, 2015).

As outlined by Beauchamp (2014), the outcomes for young people exiting statutory care are poor when compared to their counterparts. Young people leaving care are more likely to

- experience homelessness;

- experience substance abuse and/or misuse;

- experience involvement with the criminal justice system;

- experience physical and/or sexual assault; and

- have children who are removed from their care.

In addition, young people exiting the OOHC system are more likely to be unemployed or in low skilled, low paid roles and are significantly less likely to commence and complete tertiary education (Beauchamp, 2014). Given the lack of consistent data collected on care leavers after they turn 18 , it is difficult to produce a definitive statistic on the amount of care leavers who enrol and complete higher education (Harvey, McNamara, Andrewarth, \& Luckman, 2015). A survey completed by the CREATE Foundation noted that of the respondents, only $2.8 \%$ had undertaken a higher education qualification (McDowall, 2009).

While care leavers are not a recognised equity group under the identified six underrepresented groups in higher education, Harvey et al. (2015) suggest that care leavers can be considered a sub-set of these groups, given that care leavers are more likely to be from low socioeconomic backgrounds, exit from OOHC back into a low socioeconomic situation and are more likely to be from an Aboriginal and Torres Strait Island (ATSI) background.

Despite making up only $5 \%$ of the population aged $0-17,35 \%$ of the children and young people in OOHC are ATSI (NSW Family and Community Services, 2014). In order to be culturally responsive given this 
overrepresentation, the Hunter-based Aboriginal OOHC service Wandiyali and UON's Wollotuka Institute have been providing vital experience, input and feedback to LLG. Ongoing collaboration through the LLG Consultation Group occurs through several Hunter Central Coast agencies-Allambi Youth Services, Wandiyali Aboriginal Services, Southern Settlement International and Connecting Carers.

As well as through community consultation, LLG was developed based on findings from two large-scale studies; the European study Young People from a Public Care Background: Pathways to Education in Europe (YiPPEE) (Jackson \& Cameron, 2011) and the United Kingdom study By Degrees: Going from Care to University (Jackson, Ajayi, \& Quigley, 2005). Both studies suggest that care leavers are more likely to succeed in higher education if they have access to stable accommodation, financial assistance, social supports and practical assistance (Jackson et al., 2005; Jackson \& Cameron, 2011). While there is less Australian literature outlining the experiences of care leavers in higher education, the existing literature outlines similarities with both the European and United Kingdom findings in protective factors supporting education (Harvey et al, 2015). In an Australian context, given the number of national and state inquiries into the poor outcomes of children and young people in $\mathrm{OOHC}$, it is of national interest that this area in relation to higher education is also explored (Fernandez, Bolitho, Hansen, Hudson, \& Kendall, 2014; Raman, Reynolds, \& Khan, 2011; Sammut, 2011; McHugh, Pell, \& Street, 2013).

The scoping work for LLG commenced in 2015. After successfully gaining funding through the Higher Education Participation and Partnerships Program's (HEPPP) National Priorities Pool funding, the first cohort commenced in the program in 2016. LLG was developed and aimed at increasing university access, participation and success by care leavers through the facilitation of supported, subsidised on-campus accommodation and a university-based Navigator/Linker role designated to assisting transition and navigating the at times complex internal systems of a higher education institution. The Navigator/Linker also works with school-aged children and young people, their carers, birth families, teachers and case workers, to commence a conversation about the possibility of higher education.

LLG's aims are twofold: to assist care leavers to succeed once they are on-campus and to encourage young people in $\mathrm{OOHC}$ in high school to transition on to higher education. A strength-based, solution-focused methodology has proven successful with adolescent care leavers and has been used in the program (Payne, 2014; Malekoff, 2014).

The table below outlines the main similarities outlined in Australian and international studies and how LLG has sought to meet the needs identified in the studies.

\section{Impact/major findings to date}

While we anticipated that the designated oncampus Navigator/Linker role would be important, we underestimated how pivotal the role is. Anecdotally, every participant in our first cohort indicated that they would have left university study within the first four weeks of semester if not for the assistance of the Navigator/Linker. This role has walked alongside participants in a respectful and reassuring peer role, contributing to selfdetermination as opposed to challenging it. The Navigator/Linker role has also demonstrated importance in capacity building amongst UON staff and external stakeholders.

Several internal systemic issues such as difficult online enrolment processes have emerged as potential barriers to retention in 
Live, Learn, Grow: Supporting young people with a care experience through higher education

\begin{tabular}{|c|c|c|c|c|}
\hline \multicolumn{5}{|c|}{ Contemporary national and international studies into $\mathrm{OOHC}$ and higher education } \\
\hline $\begin{array}{l}\text { Impacting factors to } \\
\text { success }\end{array}$ & La Trobe & YiPPEE & $\begin{array}{c}\text { By } \\
\text { Degrees }\end{array}$ & $\begin{array}{c}\text { UON pilot } \\
\text { Live Learn Grow }\end{array}$ \\
\hline $\begin{array}{l}\text { Practical ongoing } \\
\text { assistance }\end{array}$ & $\checkmark$ & $\checkmark$ & $\checkmark$ & $\begin{array}{l}\text { The development of a new, on-campus } \\
\text { Navigator/Linker role designed to assist care } \\
\text { leavers with the transition through the first year of } \\
\text { university. }\end{array}$ \\
\hline $\begin{array}{l}\text { Stable } \\
\text { accommodation }\end{array}$ & $\checkmark$ & $\checkmark$ & $\checkmark$ & $\begin{array}{l}\text { Designated on-campus residential placements } \\
\text { including food at a subsidised rate for a period of } 12 \\
\text { months. }\end{array}$ \\
\hline Financial stability & $\checkmark$ & $\checkmark$ & $\checkmark$ & $\begin{array}{l}\text { Participants will be offered guaranteed on-campus } \\
\text { employment. Employment will be flexible so as to } \\
\text { not impact on study. Employers will be mindful of } \\
\text { the potential additional workplace development } \\
\text { needs of the participants. }\end{array}$ \\
\hline $\begin{array}{l}\text { Social outlets and } \\
\text { supports }\end{array}$ & $\checkmark$ & $\checkmark$ & $\checkmark$ & $\begin{array}{l}\text { Participants are supported to link in with one of the } \\
100+\text { UON on-campus social groups. }\end{array}$ \\
\hline $\begin{array}{l}\text { Attention paid to } \\
\text { education in case } \\
\text { planning throughout } \\
\text { care placement/s }\end{array}$ & $\checkmark$ & $\checkmark$ & $\checkmark$ & $\begin{array}{l}\text { 1) The Navigator/Linker role works with students } \\
\text { with a care experience in years 10,11,12, their } \\
\text { teachers, carers and birth families where appropriate } \\
\text { to start the transition to contemplating higher } \\
\text { education. } \\
\text { 2) UON has extended its existing on-campus visits } \\
\text { for children and young people in OOHC, their } \\
\text { carers and teachers to demystify the university } \\
\text { experience. } \\
\text { 3) UON offers on-campus development days for } \\
\text { educators and case workers, presenting the most up } \\
\text { to date theories and practical applications for } \\
\text { working with children and young people in OOHC }\end{array}$ \\
\hline
\end{tabular}

our first group of participants. The systemic issues highlighted through the LLG have been assessed and changed due to the program.

Of absolute importance to the program's success is the strength of LLG's community collaborative process. In a short period of time, the work of LLG has contributed to changing practice within the OOHC sector with casework staff and organisations stating they are taking new steps to better promote education as part of their core business. UON learns from the skills and expertise of our LLG partners in a continual drive to improve our knowledge and ability to provide best practice service.

Praxis-based research is currently being developed for LLG, which will be discussed in further publications.

\section{Outcomes from 2017 STARS Conference presentation}

After the presentation of the LLG program at the STARS Conference, attendees were given the opportunity to provide feedback and ask 
further questions. They were also asked to discuss the question: How are other universities working with and supporting care leavers? One attendee commented that their institution had included questions in their scholarship application process to capture information about students' previous experience of care, and that their state tertiary admissions centre had also begun to capture this information as part of the application process.

A peer mentoring program was suggested, pairing students who have completed the LLG program with current participants to provide extra support. The importance of working closely with carers and caseworkers was also discussed. Attendees noted the significance of the impact a program such as Live, Learn, Grow may have on carers' and caseworkers' attitude towards and understanding of education, and the options available to the children in their care.

\section{References}

Australian Institute of Health and Welfare. (2011) Educational outcomes of children on guardianship or custody orders: a pilot study, Stage 2. Child Welfare Series no. 49. Cat. CWS 37. Retrieved from the Australian Institute of Health and Welfare website http://www.aihw.gov.au/publicationdetail/?id=6442475489

Beauchamp, T. (2014). A strong future for young people leaving out of home care: Uniting Care Children, Young People and Families position paper on leaving care and aftercare. Retrieved from Australian Institute of Health and Welfare https://uniting.org/data/assets/pdf file/0005/12 6905/UnitingCare-CYPF-position-paper-a-strongfuture-for-young-people-leaving-00HC.pdf

Fernandez, E., Bolitho, J., Hansen, P., Hudson, M., \& Kendall, S. (2014). A Study of the Children's court of New South Wales. Retrieved from http://www.childrenscourt.justice.nsw.gov.au/Docu ments/chcourt $\% 20$ assessment.pdf

Harvey, A., McNamara, P., Andrewartha, L., \& Luckman, M. (2015). Out of care, into university: raising higher education access and achievement of care leavers. Retrieved from the National Centre for Student Equity in Higher Education (NCSEHE) website https://www.ncsehe.edu.au/publications/out-of- care-into-university-raising-higher-educationaccess-and-achievement-of-care-leavers/

Jackson, S., \& Cameron, C. (2011). Final report of the YiPPEE project-WP 12. Young People from a Public Care Background: Pathways to further and higher education in five European countries. Retrieved from http://www.kineo.nu/skolfam/moodle/pluginfile.ph $\mathrm{p} / 35 / \mathrm{mod}$ resource/content/1/Final $\% 20$ Report $\% 2$ 0of $\% 20$ the $\% 20$ YiPPEE $\% 20$ Project $\% 20$ \%20WP12\%20Mar11.pdf

Jackson, S., Ajayi, S., \& Quigley, M. (2005). Going to university from care. Institute of Education, University of London.

Malekoff, A. (2014). Group work with adolescents: Principles and practice ( $3^{\text {rd }}$ ed.). New York, NY: Guilford

McDowall, J.J. (2009) CREATE Report Card 2009. Transitioning from care: Tracking progress. Retrieved from CREATE Foundation website https://create.org.au/publications/researchreports/

McHugh, M., \& Pell, A. (2013). Reforming the Foster Care System in Australia: A new model of support, education and payment for foster parents. Retrieved from

http://www.childhoodinstitute.org.au/Assets/563/ 1/ReformingtheFosterCareSysteminAustralia.pdf

NSW Family and Community Services. (2015). OOHC Transition Dashboard, February 2015. Retrieved from http://www.community.nsw.gov.au/ data/assets/fi le/0008/336653/jul13jun15 transition dashboard snapshot.pdf

NSW Family and Community Services. (2014). Community Services annual statistical report 2012/13 Sydney. Retrieved from http://www.community.nsw.gov.au/ data/assets/p df file/0012/322005/annual statistical report 2012 -13.pdf

Payne, M. (2014). Modern social work theory (4th ed.). London: Palgrave Macmillan.

Raman, S., Reynolds, S., \& Khan, R. (2011). Addressing the well-being of Aboriginal children in out-of-home care: Are we there yet? Journal of paediatrics and child health, 47(11), 806-811. doi: 10.1111/j.14401754.2011.02030.x

Sammut, J. (2011). Do not damage and disturb: On child protection failures and the pressure on out-of-home care in Australia. Retrieved from the Centre for Independent Studies website https://web.archive.org/web/20120703151654/htt p://www.cis.org.au/images/stories/policymonographs/pm-122.pdf 